\title{
The Effect of Different Proportions of Rosehip (Rosa canina, L.) Oil Added to Rainbow Trout (Oncorhynchus mykiss, L.) Feed on Growth Growth Performance ${ }^{[*]}$
}

\author{
Obey ALNAIEM ${ }^{1}$ Hamdi AYDIN ${ }^{2 *}$ \\ ${ }^{1}$ Kocaeli University, Institute of Science, Fisheries Master Student, Umuttepe, Kocaeli, Turkey \\ ${ }^{2 *}$ Kocaeli University, Faculty of Agriculture, Department of Fisheries, Kartepe, Kocaeli, Turkey
}

How to cite: Alnaiem, O. \& Aydın, H. (2021). The Effect of Different Proportions of Rosehip (Rosa canina, L.) Oil Added to Rainbow Trout (Oncorhynchus mykiss, L.) Feed on Growth Growth Performance. J. Anatolian Env. and Anim. Sciences, 6(2), 217-223.

Atıf yapmak için: Alnaiem, O. \& Aydın, H. (2021). Gökkuşağı Alabalığı (Oncorhynchus mykiss, L.) Yemlerine Eklenen Farklı Oranlardaki Kuşburnu (Rosa canina, L.) Yağının Büyüme Performansına Etkisi. Anadolu Çev. ve Hay. Dergisi, 6(2), 217-223.

D: https://orcid.org/0000-0002-9014-9583 * (iD): https://orcid.org/0000-0002-3854-6047

\begin{abstract}
In this study, the effects of rosehip (Rosa canina L.) oil added to the diets of juvenile rainbow trout (Oncorhynchus mykiss W.) at different rates on the growth performance, feed efficiency and survival rate of fish were investigated. For this purpose, rosehip oil in 4 different concentrations $(0,2,4$ and $6 \mathrm{ml} / \mathrm{kg})$ was added to the feed of juvenile trout with an initial average weight of $1.7 \pm 2.8 \mathrm{~g}$, for 90 days $\left(\mathrm{pH} 7.15-8.33\right.$, temperature $12.3-15.9^{\circ} \mathrm{C}$ and dissolved oxygen in the range $6.85-10.8 \mathrm{mg} / \mathrm{l})$. The experimental groups were planned with 2 replications and 200 juvenile fish were placed in each tank and a total of 1600 fish were studied. At the end of the experiment, the highest increase in live weight was obtained in the IV. group in which $53.71 \pm$ $1.12 \mathrm{~g}$ and $0.71 \pm 0.02$ feed conversion rate and $6 \mathrm{ml} / \mathrm{kg}$ rosehip oil was added and the difference was statistically significant compared to the other groups $(\mathrm{P}<0.05)$. As a result; in this study, it was determined that the addition of Rosehip oil to juvenile trout feeds increased the rate of feed efficiency to fish and had a positive effect on the development of fish.
\end{abstract}

*Corresponding author's:

Hamdi AYDIN

Kocaeli Üniversitesi, Faculty of Agriculture,

Department of Fisheries, Kartepe, Kocaeli,

Turkey.

\: aydin@kocaeli.edu.tr

Keywords: Rainbow trout, Oncorhynchus mykiss, rosehip oil, Rosa canina, growth performance.

\section{Gökkuşağı Alabalığı (Oncorhynchus mykiss, L.) Yemlerine Eklenen Farklı Oranlardaki Kuşburnu (Rosa canina, L.) Yağının Büyüme Performansına Etkisi}

\author{
*Sorumlu yazar: \\ Hamdi AYDIN \\ Kocaeli Üniversitesi, Ziraat Fakültesi, Su \\ Ürünleri Bölümü, Kartepe, Kocaeli, Türkiye. \\ 凶: aydin@kocaeli.edu.tr
}

Öz: Bu çalışmada yavru gökkuşağı alabalığı (Oncorhynchus mykiss W.) yemlerine farklı oranlarda ilave edilen Kuşburnu (Rosa canina L.) yağının, balıkların büyüme performansı, yemden yararlanma ve yaşama oranı üzerine etkileri araştırılmıştır. $\mathrm{Bu}$ amaçla, başlangıç ortalama ağırlıkları $1,7 \pm 0,11 \mathrm{~g}$ olan yavru alabalıkların yemlerine 4 farklı konsantrasyonda 0 $\mathrm{ml} / \mathrm{kg}, 2 \mathrm{ml} / \mathrm{kg}, 4 \mathrm{ml} / \mathrm{kg}$ ve $6 \mathrm{ml} / \mathrm{kg}$ olacak şekilde Kuşburnu yağı ilave edilerek 90 gün boyunca (pH 7,15-8,33, sıcaklık 12,3-15,9 ${ }^{\circ} \mathrm{C}$ ve çözünmüş oksijen $6,85-10,8 \mathrm{mg} / \mathrm{l}$ aralığında) beslenmiştir. Deneme grupları 2 tekerrürlü olarak planlanmış ve her bir tanka 200 adet yavru balık konularak toplamda 1600 adet balıkla çalışma yürütülmüştür. Deneme sonunda en yüksek canlı ağırlık artışı $(53,71 \pm 1,12 \mathrm{~g})$ ve $(0,7 \pm 0,02)$ yem dönüşüm oranı ile $6 \mathrm{ml} / \mathrm{kg}$ Kuşburnu yağ 1 ilave edilen IV. grupta elde edilmiş ve diğer gruplara göre istatistiksel olarak fark önemli çıkmıştır $(\mathrm{P}<0,05)$. Sonuç olarak; bu çalışmada, kuşburnu yağının yavru alabalık yemlerine ilave edilmesi ile balıkların yemden yaralanma oranının arttığı ve balıkların gelişmelerinde de olumlu etkiye sahip olduğu tespit edilmiştir.

Anahtar kelimeler: Gökkușağı alabalığı, Oncorhynchus mykiss, kușburnu yağı, Rosa canina, büyüme performansi. 


\section{INTRODUCTION}

Aquaculture is the fastest growing food producing sector in the world and especially it has made very rapid progress in the last 30 years. The global population is increasing, thus, the demand for aquatic food products is also increasing. With capture fisheries becoming increasingly unsustainable due to excessive and unconscious fishing, aquaculture is expected to overtake capture fisheries in supplying the world's protein requirements in the future. Fish and other aquaculture supply at least $20 \%$ of the animal protein source of people in developing countries and more than $50 \%$ of people in poor countries of Africa and South Asia (Awad \& Awaad, 2017). The intensification of rearing methods and systems has created a stressful environment in the fish that can cause suppression of the immune system and increase the susceptibility of the fish to infectious diseases. In addition, many negative factors such as high stocking density, aquaculture practices, temperature, poor water quality and insufficient feeding, cause stress in the fish and increase the risk of catching a disease (Elumalai et al., 2020, Hoseinifar et al., 2020).

A wide variety of antibiotics and chemicals are used to control infectious diseases in fish farms. Although antibiotics are generally successful in treating diseases, they cause the accumulation of antibiotic residues in either the environment or fish tissues and the emergence of antimicrobial resistant species (Rossolini et al,, 2014; Santos \& Ramos, 2016). Vaccines used in fish farms are expensive and have a specific action against only one pathogen (Harikrishnan et al., 2011; Sakai, 1999). Therefore, there is a global trend towards the use of medicinal plants and their derivatives in aquaculture as an alternative method to prevent or control fish diseases (Harikrishnan et al., 2011; Reverter et al., 2014; Van Hai., 2015, Elumalai et al., 2020; Hoseinifar et al., 2020).

In aquaculture, some feed additives are often added to feeds to increase feed efficiency, growth performance and survival rates. As feed additives, yeasts, colorants, amino acids, antioxidants, enzymes, probiotics, prebiotics, algae, lipid derivatives, nutraceuticals, vitamins, plant extracts and certain organic acids / salts, carnitine, hormones and aromatic compounds can be listed (Kıvrak, 2017; Yazıcı \& Mazlum, 2019; Mazlum et al., 2021). However, intensive and semi-intensive practices of aquaculture cause an increase in disease outbreaks and cause partial or total losses in fish production (Awad \& Awaad, 2017). That is why in recent years, researchers and fish farmers have started to use in fish feed some plants and oils obtained in fish feed some plants and oils obtained from plants. It has been understood that these herbal products are beneficial for humans and fish as well as for the environment. Some plants have been used as an inexpensive protein source instead of the protein in fish meal and it has been found that they are effective in this regard and positively affect the growth and immune system (Ngo, 2015; Ramasamy et al., 2011; Reverter et al., 2014; Hoseinifar et al., 2020).

Studies have proven that medicinal and aromatic plants have growth-promoting and stress-reducing properties in fish. First of all, medicinal and aromatic plants have started to be used because they are natural and cheap, as well as increasing the survival rate and development of aquatic animals by purifying digestive enzymes (Ngo, 2015).

Turkey in medicinal and aromatic plants has an extremely rich flora (Akalın, 2020). Rosehip (Rosa canina L.) plants and is one of the most important of these plants are abundant on each side of Turkey. While it has been widely used for fruit juice, jam, marmalade and tea for many years (Ercişli, 1996; Ercişli \& Güleryüz, 2005), it is a plant that has been processed for its oil in recent years (Valeron et al., 2015; Kıralan \& Yıldırım, 2019). Rosehip plant is a rich source of vitamin $\mathrm{C}$ and is also rich in anthocyanins, phenolic ingredients and carotenoids. Used in a variety of food products as well as in the perfume and cosmetic industries. It is traditionally used to treat influenza, inflammation, and chronic pain (Guimaraes et al., 2010). In addition, phenolics are considered as phytochemicals responsible for the antioxidant activity of plant materials, so they are known as the most effective remedy against hemorrhoids and diabetes in Turkish folk medicine (Jamaa et al., 2017; Deliorman et al., 2007). Rosehip is also rich in polyunsaturated fatty acids (Szentmihalyi et al., 2002). The lipid fraction of rosehip seed contains more than $50 \%$ of polyunsaturated fatty acids, and Rosehip seed oil is used in cosmetics due to its therapeutic effect on skin ailments (İlyasoğlu, 2014). It has a rich mineral source (potassium, phosphorus), vitamins (vitamin C), carotenoids and aroma components (Shnyakina \& Malygina, 1975; Oszmianski \& Chomin, 1993).

Although the rosehip plant well-documented the positive effects on the nutrition and immune systems of humans and animals. There is very limited information about its used as a feed supplement in aquaculture. It was studied in sturgeon "Huso huso" (Dadras et al., 2016), rainbow trout "Oncorhynchus mykiss" (Sahan et al., 2017), Russian Sturgeon "Acipenser gueldenstaedti" (Duman and Sahan, 2018), common carp "Cyprinus carpio" (Dogru et al., 2018). This is the first research to use rosehip oil in fish as feed additive. The present study, therefore aims to investigate the growth, survival rate and feed conversion 
rates of fish by adding oil obtained from Rosehip plant to juvenile trout feeds.

\section{MATERIAL AND METHOD}

This research was carried out in Sapanca Inland Fisheries Production Research and Application Unit affiliated to Istanbul University Faculty of Aquatic Sciences. The trial period was planned as 90 days and was conducted between 18 February and 18 May 2020. In the research, 1,600 rainbow trout (Oncorhynchus mykiss, W.) with an average weight of $1.7 \pm 0.11 \mathrm{~g}$ were used. 200 fish were stocked in 8 cylindrical tanks with a capacity of 350 liters with 2 replicates. Attention was paid to ensure that the selected fish for the experiment were unvaccinated before and apparently healthy fish with no prior history of any diseases. Fish health conditions were checked visually by observing the body and fins of the fish, the absence of disease symptoms, as well as regular movements.

Before the experiment, the fish were hand-fed daily for 2 weeks with commercial trout feed until they were apparent satiation for adaptation to the experimental environment. The proximate analysis of the control feed used in the trial was done according to AOAC, 1998 (Table 1). Uneaten food and fish wastes were regularly cleaned daily. During the research, the stream water used in the unit was supplied to the tanks. Water temperature, $\mathrm{pH}$ and dissolved oxygen values were measured weekly and It was recorded that the $\mathrm{pH}$ was between $7.15-8.33$, temperature 12.3-15.9 ${ }^{\circ} \mathrm{C}$ and dissolved oxygen $6.85-10.8 \mathrm{mg} / 1$.

Table 1.Analysis of trout feed used in research*

Tablo 1. Araştırmada kullanılan alabalık yeminin analizi*

\begin{tabular}{lc}
\hline Feed Analysis & \% \\
\hline Ash & 14.65 \\
Crude protein & 54.58 \\
Crude fiber & 0.63 \\
Raw oil & 12.05 \\
\hline * Kocaeli Provincial Food Control Laboratory
\end{tabular}

The rosehip oil used in the experiment was previously market researched and the oils purchased from different brands were analyzed, and as a result of this analysis, it was decided to use the best oil in the trial. Analysis of rosehip oil was made according to TS EN ISO 12966-2 standard (TS EN ISO 12966-2, 2017). Analysis results of rosehip oil used in the experiment are given in Table 2.

4 different treatments groups were prepared. Rosehip oil was first diluted in alcohol and sprayed on the feed so that it was mixed thoroughly to assure homogeneity. Rosehip oil was supplemented to basal diet as $0 \mathrm{mg} / \mathrm{kg}$ (I. Group), $2 \mathrm{ml} / \mathrm{kg}$ (II. Group), $4 \mathrm{ml} / \mathrm{kg}$ (III. Group) and $6 \mathrm{ml} / \mathrm{kg}$ (IV. Group). In the first month of the experiment, the fish were hand-fed 7-8 times a day, 5-6 times a day in the second month and 4-5 times a day in the last month until they were apparent satiation.
Table 2. Analysis results of Rosehip oil used in the trial

Tablo 2. Araştırmada kullanılan kuşburnu yağının analiz sonuçları*

\begin{tabular}{lc}
\hline Fatty acids & $\mathbf{( \% )}$ \\
\hline Lauric acid/Dodecanoic acid C12:0 & 0.10 \\
Myristic/Tetradecanoic acid C14:0 & 0.05 \\
Palmitic/Hexadecaoic acid C16:0 & 3.78 \\
Palmitoleic acid C16:1 & 0.08 \\
Stearic/Octadecanoic acid C18:0 & 2.05 \\
Oleic acid C18:1 & 24.43 \\
Linoleic acid C18:2 & 49.02 \\
Linolenic acid C18:3 & 18.74 \\
Arachidic acid C20:0 & 0.89 \\
Elcosanoic (Gadoleic) acid C20:1 & 0.40 \\
Docosenoic/Eucic acid C22:1 & 0.16 \\
Behenic acid C22:0 & 0.21 \\
\hline
\end{tabular}

*Kocaeli Provincial Food Control Laboratory

\section{Growth Performance Calculations}

Live weight $(\mathrm{g})$ measurements of the fish were made every end of month during the experiment. Fish weights were made with a scale with $0.01 \mathrm{~g}$ precision.

The parameters were measured according to the following formulas (Çilingir, 2017).

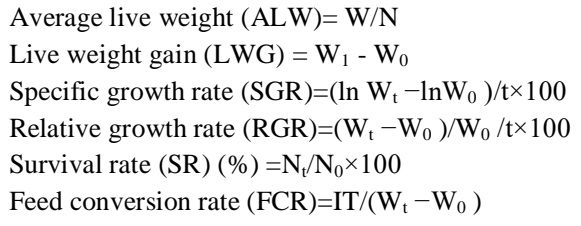

Where $\mathrm{W}$ is the total weight of fish, $\mathrm{N}$ is the number of fish, $\mathrm{W}_{\mathrm{t}}$ is the body weight $(\mathrm{g})$ on the specific sampling day, $\mathrm{W}_{0}$ is the initial body weight $(\mathrm{g})$ at the beginning of the trial, $t$ is feeding duration in days from the beginning of the trial until the specific sampling day, IT is the total dry diet intake ( $\mathrm{g}$ ) from the beginning of the trial to the specific sampling day, $\mathrm{Lt}$ is fish length $(\mathrm{cm})$ on the specific sampling day.

\section{Statistical Analysis}

The data obtained in the experiment were evaluated with the one-way Anova test. While comparing the importance of various parameters examined in the experiment, the results are given as mean value and standard deviation. The distinction between groups was determined by analysis of variance and comparison of groups by Duncan multiple comparison test, and the significance level was chosen as $\mathrm{P}=0.05$ (Özdamar, 2001).

\section{RESULTS}

Growth performance parameters are listed in Table 3. In the I. Group where Rosehip oil was not added, the average live weight of the fish was $1.67 \pm 0.02 \mathrm{~g}$ at the beginning of the experiment were increased to $52.03 \pm 2.38$ $\mathrm{g}$ after 90 days, fish in the II. Group $(2 \mathrm{ml} / \mathrm{kg})$ from 1.93 $\pm 0.01 \mathrm{~g}$ to $52.44 \pm 1.44 \mathrm{~g}$, the fish in the III. Group ( $4 \mathrm{ml} /$ $\mathrm{kg}$ ) from $1.88 \pm 0.04 \mathrm{~g}$ to $52.25 \pm 0.04 \mathrm{~g}$ and It was 
determined that the fish in the IV. Group $(6 \mathrm{ml} / \mathrm{kg})$ reached from $1.84 \pm 0.09 \mathrm{~g}$ to $55.55 \pm 1.02 \mathrm{~g}$. The average weight gains were also found to be $50.36 \pm 2.36 \mathrm{~g}, 50.51 \pm$ $1.44 \mathrm{~g}, 50.37 \pm 0.07 \mathrm{~g}$ and $53.71 \pm 1.12 \mathrm{~g}$ in the groups, respectively. Relative growth rates in the groups were determined as $3015 \pm 103 \%, 2617 \pm 85 \%, 2679 \pm 64 \%$ and $2919 \pm 63 \%$, respectively (Table 3 ).

When looking at the specific growth rate values in groups I. Group, II. Group and III. While the values obtained in the group were the same $(0.56 \pm 0.02)$, the highest value $(0.60 \pm 0.01)$ was IV. Group $(6 \mathrm{mg} / \mathrm{kg})$ (Table 3). Considering the feed conversion ratio values, I. Group, II. Group and III. Group while $0.8 \pm 0.01$ in the group, it was found to be $0.7 \pm 0.02$ in the IV. Group. Feed consumption and total live weight gain are given in Table 3. The survival rate (SR) value in the groups was determined $98.5 \pm 1.41 \%, 97 \% \pm 1.41,98.5 \pm 0.35 \%$ and $98.5 \pm 0.07 \%$ respectively (Table 3 ).

Table 3. Different growth parameters of trial groups.

Tablo 3. Deneme gruplarına ait farklı büyüme parametreleri.

\begin{tabular}{|c|c|c|c|c|}
\hline & I.Group & II.Group & III.Group & IV.Group \\
\hline İnitial average live weight (g) & $1.67 \pm 0.02$ & $1.93 \pm 0.01$ & $1.88 \pm 0.04$ & $1.84 \pm 0.09$ \\
\hline Final average live weight (g) & $52.03 \pm 2.38$ & $52.44 \pm 1.44$ & $52.25 \pm 0.04$ & $55.55 \pm 1.02 *$ \\
\hline Average weight gain $(\mathrm{g})$ & $50.36 \pm 2.36$ & $50.51 \pm 1.44$ & $50.37 \pm 0.07$ & $53.71 \pm 1.12 *$ \\
\hline Relative growth rate $(\%)$ & $3.015 \pm 103$ & $2.617 \pm 85$ & $2.679 \pm 64$ & $2.919 \pm 63$ \\
\hline Specific growth rates (\%) & $0.56 \pm 0.02$ & $0.56 \pm 0.02$ & $0.56 \pm 0.02$ & $0.60 \pm 0.01 *$ \\
\hline Survival rate $(\%)$ & $98.5 \pm 1.41$ & $97.0 \pm 1.41$ & $98.5 \pm 0.35$ & $98.5 \pm 0.07$ \\
\hline Total feed consumption (g) & 7.875 & 7.725 & 7.815 & 7.475 \\
\hline Feed conversion rate & $0.8 \pm 0.01$ & $0.8 \pm 0.01$ & $0.8 \pm 0.00$ & $0.7 \pm 0.02 *$ \\
\hline
\end{tabular}

$\left({ }^{*}\right)$ Values marked with * are statistically significant from other groups $(\mathrm{p}<0.05)$

\section{DISCUSSION AND CONCLUSION}

In this study, the effect on growth and feed utilization of rainbow trout (Oncorhynchus mykiss) juveniles fed with feeds containing different ratios of rosehip oil ( $R$. canina) survival rate was firstly examined and discussed in comparison with previous studies.

Ahmad et al., (2016) reported that rosehip plant contains $3.78 \%$ palmitic acid, $0.08 \%$ palmitoleic acid, $24.43 \%$, oleic acid, $49.02 \%$ linoleic acid, $18.74 \%$ and $18.74 \%$ linolenic acid in the chemical composition. Analysis results of Rosehip oil that we used in our study were found to be $3.54 \%, 0.06 \%, 20.30 \%, 51.67 \%$ and $19.08 \%$, respectively, according to the above values, and these results are close to the results found by Ahmad et al., (2016).

Studies on adding medicinal and aromatic plants to fish feed have been gained importance in recent years. When some medicinal and aromatic plants and extracts obtained from them are added to fish feeds, positive effects such as weight gain, specific growth rate and increase in feed efficiency ratio and reduction in feed conversion ratio have been determined (Aly, et al., 2008; Aly \& Mohamed, 2010; Immanuel et al., 2009; Ji et al., 2007; Nya \& Austin, 2009a, 2009b; Punitha et al., 2008; Shalaby et al., 2006). It has been reported that garlic, onion, marjoram, cumin, basil, anise, fennel, icoria, black cumin and fenugreek stimulate the growth of fish (Sivaram et al., 2004). Mahdavi et al., (2013) reported that the addition of aloe vera extract in different ratios $(0.1,0.5$ and $2.5 \%)$ to carp (Cyprinus carpio) fish feeds had a positive effect on the development of the fish as a result of feeding for 8 weeks and had an appetite-enhancing feature. Zheng, (2009) reported that feed conversion ratio decreased, weight gain, specific growth rate and survival rates increased in catfish fed with feeds with added marjoram (O. vulgare) essential oil. Gabor et al., (2011) reported that they added $1 \%$ ginger, $2 \%$ garlic, $1 \%$ thyme and $2 \%$ echinacea to rainbow trout feed, and a significant increase was observed in the final weight value, bodyweight, specific growth rate and proportional growth rates of fish. Acar, (2018) also suggested that St. John's Worth Oil (Hypericum perforatum) supplemented to the carp diet at the rate of $5 \mathrm{~g}$ $/ \mathrm{kg}$ in the ration can be used without any negative effects on growth performance and blood parameters.

In our study, it was observed that the addition of rosehip oil to rainbow trout diets positively affected their development. The best growth rate was obtained in the group to which $6 \mathrm{mg} / \mathrm{kg}$ (IV. Group) rosehip oil was added and this value was found to be statistically significant compared to the control group $(\mathrm{P}<0.05)$. Whereas, Dadras et al., (2016) found that rosehip (Rosa canina) and safflower (Carthamus tinctorium) was added to juvenile Huso huso feeds in different proportions and there were no significant differences in feed conversion ratio (FCR), specific growth rate (SGR) and condition factor $(\mathrm{K})$ but they found that there are significant differences in white blood cell (WBC) and hemoglobin $(\mathrm{Hb})$ values. The best results were obtained in the group with $2 \%$ rosehip and safflower added and these results were observed to be significant compared to the control groups. In our study, it was determined that the rosehip oil plays an important role in the development of fish due to the use of oil instead of the plant. 
Çilingir, (2017) reported that amber (Hypericum perforatum) oil added to rainbow trout (Oncorhynchus mykiss) diets had an effect on growth performance, some environmental stress parameters and antioxidant activity. Kıvrak, (2017) observed that rosemary (Rosmarinus officinalis) oil has effects on the growth performance, hematological and biochemical parameters in rainbow trout, and that the addition of rosemary oil is not effective in fish feed intake. In our study, it was determined that the addition of rosehip oil plant to trout feed, it was effective in the increase in live weight and specific growth rates in fish, but not in the survival rate.

In conclusion, it is well-known that the use of suitable feed for feeding during the juvenile period of rainbow trout has a positive contribution to the development and survival rates of fish. In recent years, with the addition of natural additives to fish feed, there has been an increase in fish development, survival rate, feed evaluation and increasing the immune system. This research has been a preliminary study on the use of rosehip oil in fish feed. It has been determined that the oil obtained from the rosehip plant has a positive effect on the growth and feed utilization rate of fish with the addition of the feeds of rainbow trout. Additionally, studies need to be carried out on the use of rosehip oil in different ratios to different fish species feed. Further studies can also be carried out to determine the hematological parameters, immune parameters, and resistance of diseases of fish fed with rosehip oil or rosehip.

\section{ACKNOWLEDGEMENTS}

We would like to thank Kocaeli University Scientific Research Projects Coordinator (Project No: FYL-2020/2086) for supporting this study summarized from the master's thesis.

\section{REFERENCES}

Acar, Ü. (2018). Sar1 kantaron (Hypericum perforatum) yağının sazan yavrularının (Cyprinus carpio) büyüme performansı ve bazı kan parametreleri üzerine etkisi. Alinteri Zirai Bilimler Dergisi, 33(1), 21-27. DOI: 10.28955/alinterizbd.343202

Ahmad, N., Anwar, F. \& Gilani, A.U. (2016). Rose hip (Rosa canina L.) oils. In: Preedy, V.R. (Ed.), Essential Oils in Food Preservation, Flavor and Safety. Academic Press, 667-675. DOI: 10.1016/B978-0-12-416641-7.00006-7

Akalın, E., Gurdal, B. \& Olcay, B. (2020). General overview on the conservation of medicinal plants in Turkey. Turkish Journal of Biodiversity, 3(2), 86-94.

Aly, S.M., Atti, N.M.A. \& Mohamed, M.F. (2008). Effect of garlic on the survival growth resistance and quality of Oreochromis niloticus. 8th International Symposium on Tilapia in Aquaculture, Cairo, Egypt, 12-14 Oct 2008.

Aly, S.M. \& Mohamed, M.F. (2010). Echinacea purpurea and allium sativum as immunostimulants in fish culture using Nile tilapia (Oreochromis niloticus). Journal of Animal Physiology and Animal Nutrition, 94(5), 31-39. DOI: 10.1111/j.14390396.2009.00971.x.

AOAC. (1998). Official Methods of Analysis. 16th Edition, Official Association of Official Analytical Chemists, Maryland, USA. Method 968.08.

Awad, E. \& Awaad, A. (2017). Role of medicinal plants on growth performance and immune status in fish. Fish Shellfish Immunology, 67, 40-54. DOI: 10.1016/j.fsi.2017.05.034

Çilingir, Ç. (2017). Gökkuşağı alabalığı (Oncorhynchus mykiss) yemlerine farkl oranlarda ilave edilen kantaron yağının (Hypericum perforatum) büyüme performanst, bazl çevresel stres parametreleri ve antioksidan aktivitesi üzerine etkilerinin araştırılmast. Yüksek Lisans Tezi, Süleyman Demirel Üniversitesi, Fen Bilimleri Enstitüsü, Isparta, 472418.

Dadras, H., Hayatbakhsh, M.R., Shelton, W.L. \& Golpour, A. (2016). Effects of dietary administration of rose hip and safflower on growth performance, haematological, biochemical parameters and innate immune response of Beluga, Huso huso (Linnaeus, 1758). Fish \& Shellfish Immunology, 59, 109-114. DOI: 10.1016/j.fsi.2016.10.033

Deliorman, O.D., Hartevioğlu, A., Küpeli, E. \& Yeşilada, E. (2007). In Vivo Anti-İnflammatory and Antinociceptive Activity of The Crude Extract and Fractions From Rosa canina L. fruits, Journal of Ethnopharmacology, 112, 394-400. DOI:10.1016/j.jep.2007.03.029

Dogru, A., Polat, H., Orun, I., Erdogan, K., Kandemir, S., Yilmaz, S., Orun, G., Akgül, H. \& Dogru, M.I. (2018). The effect of rosehip (Rosa canina L.) plant extract application on serum ACTH, cortisol and aldosterone hormone levels of carp (Cyprinus carpio L.) Fresenius Environmental Bulletin, 27(4), 2051-2056.

Duman, S. \& Sahan, A. (2018). Some hematological and non-specific immune responses of rosehip (Rosa canina)-Fed Russian Sturgeon (Acipenser gueldenstaedtii Brandt \& Ratzeburg, 1833) to Mycobacterium salmoniphilum. Brazilian Archives Biology and Technology, 61, 1-17. DOI: 10.1590/1678-4324-2018180283

Elumalai, P., Kurian A., Lakshmi, S., Faggio, C., Esteban, M.A. \& Ringo, E. (2020). Herbal immunomodulators in aquaculture. Reviews in Fisheries Science \& Aquaculture, 1-25. DOI: 10.1080/23308249.2020.1779651

Ercişli, S. (1996). Selection and propagation of rose hips are naturally grown in Gümüshane district. $\mathrm{Ph} . \mathrm{D}$. Thesis, Atatürk University, Erzurum. 167p. 
Ercişli, S \& Güleryüz, M. (2005). Rosehip Utilization in Turkey. Acta Horticulturae, 77-82. DOI: 10.17660/ActaHortic.2005.690.10

Gabor, E.F., Şara, A., Molnar, F. \& Benţea, M. (2011). The Influence of some phytoadditives on growth performances and meat quality in rainbow trout (Oncorhynchus mykiss). Scientic Papers Animal Science and Biotechnologies, 44, 1-2.

Guimaraes, R., Barros, L., Carvalho, A.M., Ferreira, I.C.F.R. (2010). Studies on chemical constituents and bioactivity of Rosa micrantha: an alternative antioxidants source for food, pharmaceutical, or cosmetic applications. Journal of Agricultural Food Chemistry. 58, 6277-6284. DOI: 10.1021/jf101394w

Harikrishnan, R., Balasundaram, C.M.S. \& Heo, M-S. (2011). Impact of plant products on innate and adaptive immune system of cultured finfish and shellfish, Aquaculture 317(1-4), 1-15. DOI: 10.1016/j.aquaculture.2011.03.039

Hoseinifar, S.H., Sun, Y.Z., Zhou, Z., Doan, H. Van, Davies, S.J. \& Harikrishnan, R. (2020). Boosting immune function and disease biocontrol through environment-friendly and sustainable approaches in finfish aquaculture: herbal therapy scenarios. Reviews in Fisheries Science \& Aquaculture, 1-19, DOI: 10.1080/23308249.2020.1731420

Immanuel, G., Uma, R.P., Iyapparaj, P., Citarasu, T., Punitha, P.S.M., Michael B.M.\& Palavesam, A. (2009). Dietary medicinal plant extracts improve growth, immune activity and survival of Tilapia (Oreochromis mossambicus), Journal of Fish Biology, 74, 1462-1475. DOI: 10.1111/j.1095-8649.2009.02212.x

İlyasoğlu, H. (2014). Characterization of rosehip (Rosa canina L.) seed and seed oil. International Journal of Food Properties, 17, 1591-1598. DOI: 10.1080/10942912.2013.777075

Jamaa, B.H., Jemia, B.A., Khlifi, S., Halima, B.A., Fethi, B.S., Benzarti, A., Elati J.\& Aouidet A. (2017). Antioxidant Activity and $\alpha$-Amylase Inhibitory Potential of Rosa cantna L.. African Journal of Traditional, Complementary and Alternative Medicines, 14(2), 1-8. DOI: 10.21010/ajtcam.v14i2.1

Ji, S.C., Jeong, GS., Im, G.S., Lee, S.W., Yoo, J.H. \& Takii, K. (2007). Dietary medicinal herbs improve growth performance, fatty acid utilization, and stress recovery of Japanese flounder. Fisheries Science, 73, 70-76. DOI: 10.1111/j.1444-2906.2007.01303.x

Kıralan, M. \& Yıldırım, G. (2019). Rosehip (Rosa canina L.) oil. fruit oils: Chemistry and Functionality (803-814pp) DOI: 10.1007/978-3-030-12473$1 \_43$

Kıvrak, E. (2017). Gökkuşă̆l alabalığı (Oncorhynchus mykiss, Walbaum 1792)'nın yemlerine biberiye bitki (Rosmarinus officinalis) yağı ilavesinin balıkların büyüme performansı ve bazl kan parametrelerine olan etkileri. Yüksek Lisans
Tezi, Süleyman Demirel Üniversitesi, Fen Bilimleri Enstitüsü, Isparta, 472409.

Mahdavi, M., Hajimoradloo, A. \& Ghorbani, R. (2013). Effect of aloe vera extract on growth parameters of common carp (Cyprinus carpio). World Journal of Medical Science, 8(1), 55-60. DOI: 10.5829/idosi.wjms.2013.9.1.75128

Mazlum, Y., Yazıcı, M., Sayın, S., Habiboğlu, O. \& Sinem, U. (2021). Effects of two different macroalgae (Ulva lactuca and Jania rubens) species on growth and survival of juvenile red swamp crayfish (Procambarus clarkii) as feed additive. Marine Science and Technology Bulletin. DOI: 10.33714/masteb.820627

Ngo, V.H. (2015). The use of medicinal plants as immunostimulants in aquaculture: A review. Aquaculture, 446, 88-96. DOI: 10.1016/j.aquaculture.2015.03.014

Nya, E.J. \& Austin, B. (2009a). Use of garlic, Allium sativum, to control Aeromonas hydrophila infection in rainbow trout Oncorhynchus mykiss (Walbaum). Journal of Fish Diseases, 32, 963970. DOI: 10.1111/j.1365-2761.2009.01100.x

Nya, E.J. \& Austin, B. (2009b). Use of dietary ginger Zingiber officinale Roscoe as an immunostimulant to control Aeromonas hydrophila infections in rainbow trout, Oncorhynchus mykiss (Walbaum). Journal of Fish Diseases, 32, 971-977. DOI: 10.1111/j.13652761.2009.01101.x

Oszmianski, J. \& Chomin, W. (1993). Experimental commercial manufacture of high vitamin $\mathrm{C}$ cloudy juice from Rosa rugosa fruits. Przemysl Fermentacyjny i Owocowo Warzywny, 37, 16-17.

Özdamar, K. (2001). Tıp Biyoloji Eczacılık ve Diş Hekimliği Öğrencileri için SPSS ile Biyoistatistik. Kaan Kitabevi, $452 \mathrm{~s}$.

Punitha, S.M.J., Babu M.M., Sivaram V., Shankar V.S., Dhas S.A., Mahesh T.C., Immanuel, G. \& Citarasu, T. (2008). Immunostimulating influence of herbal biomedicines on non-specific immunity in grouper epinephelus tauvina juvenile against Vibrio harveyi infection. Aquaculture International, 16, 511-523. DOI: 10.1007/s10499-007-9162-6

Ramasamy, H., Chellam, B. \& Moon, S.H. (2011). Impact of plant products on innate and adaptive immune system of cultured finfish and shellfish. Aquaculture, 317(4), 1-15. DOI: 10.1016/j.aquaculture.2011.03.039

Reverter, M., Bontemps, N., Lecchini, D., Banaigs, B. \& Sasal, P. (2014). Use of plant extracts in fish aquaculture as an alternative to chemotherapy: current status and future perspectives. Aquaculture, 433, 50-61. DOI: 10.1016/j.aquaculture.2014.05.048

Rossolini, G.M., Arena, F., Pecile, P. \& Pollini, S. (2014) Update on the antibiotic resistance crisis. Current Opinion in Pharmacology, 18, 56-60. DOI: 10.1016/j.coph.2014.09.006 
Sahan, A., Duman, S, Özesen, Ç.S,, Çinar, E. \& Bilgin, R. (2017). Determination of some hematological and non-specific immune defences, oxidative stress and histopathological status in rainbow trout (Oncorhynchus mykiss) fed rosehip (Rosa canina) to Yersinia ruckeri. Turk Journal of Fisheries and Aquatic Sciences. 17, 91-100. DOI: 10.4194/1303-2712-v17_1_11

Sakai M. (1999). Current research status of fish immunostimulants. Aquaculture, 172, 63-92. DOI: 10.1016/S0044-8486(98)00436-0

Santos, L. \& Ramos, F. (2016). Analytical strategies for the detection and quantification of antibiotic residues in aquaculture fishes: a review. Trends in Food Science \& Technology, 52, 16-30. DOI: 10.1016/j.tifs.2016.03.015

Shalaby, A.M., Khattab, Y.A., \& Abdel Rahman, A.M. (2006). Effects of garlic (Allium sativum) and chloramphenicol on growth performance, physiological parameters and survival of Nile tilapia (Oreochromis niloticus). Journal of Venomous Animals and Toxins Including Tropical Diseases, 12, 172-201. DOI: 10.1590/S167891992006000200003

Shnyakina, G.P. \& Malygina, E.P. (1975). Vitamins and phenolic compounds in the fruits of rosa species growing in the soviet far east. Rastitel Onye resursy, 11, 390-394.

Sivaram, V., Babu, M.M., Immanuel, G., Murugadass, S., Citarasu, T. \& Marian M.P. (2004). Growth and immune response of juvenile greasy groupers (Epinephelus tauvina) fed with herbal antibacterial active principle supplemented diets against Vibrio harveyi infections. Aquaculture, 237, 9-20.

DOI: 10.1016/j.aquaculture.2004.03.014

Szentmihalyi, K., Vinkler P., Lakatos, B., Illes, V \& Then M. (2002). Rose hip (Rosa canina L.) oil obtained from waste hip seeds by different extraction methods. Bioresource Technology, 82, 195-201. DOI: 10.1016/S0960-8524(01)00161-4

TS EN ISO 12966-2. (2017). Hayvansal ve bitkisel katı ve sivı yağlar- yă asitleri metil esterlerinin gaz kromotografisi - Bölüm 2: Yă̆ asitleri metil esterlerinin hazırlanması. TSE yayınları, Ankara

Valeron, A.P., Gómez-Duaso, A., Santana-Molina, N., García Bello, M. \& Carretero, G. (2015). Evolution of post-surgical scars treated with pure rosehip seed oil. Journal of Cosmetics, Dermatological Sciences and Applications. 5, 161-167. DOI: $10.4236 /$ jcdsa.2015.52019

Van Hai, N. (2015). The use of medicinal plants as immunostimulants in aquaculture: A review. Aquaculture, 446, 88-96. DOI: 10.1016/j.aquaculture.2015.03.014

Yazıcı, M. \& Mazlum, Y. (2019). Karides ve kerevit yetiştiriciliğinde prebiyotik uygulamalar. $K S \ddot{U}$ Tarım ve Doğa Dergisi, 22(1), 153-163. DOI: 10.18016/ ksutarimdoga.vi.471559
Zheng, G., Gong, S., Yu, D. \& Yuan, H. (2009). Propolis and herba epimedii extracts enhance the nonspecific immune response and disease resistance of Chinese sucker, Myxocyprinus asiaticus. Fish \& Shellfish Immunoogyl, 26(3), 467-472. DOI: 10.1016/j.fsi.2009.01.011 